\title{
Influence of natural zeolite and nitrification inhibitor on organics degradation and nitrogen transformation during sludge composting
}

\author{
Junya Zhang ${ }^{1,2} \cdot$ Qianwen Sui $^{1,2} \cdot \mathrm{Kun}_{\mathrm{Li}^{1,2}} \cdot$ Meixue Chen ${ }^{1,2} \cdot$ Juan Tong $^{1,2} \cdot \mathrm{Lu} \mathrm{Qi}^{3}$. \\ Yuansong Wei ${ }^{1,2}$
}

Received: 30 June 2015 / Accepted: 26 August 2015 /Published online: 11 September 2015

(C) Springer-Verlag Berlin Heidelberg 2015

\begin{abstract}
Sludge composting is one of the most widely used treatments for sewage sludge resource utilization. Natural zeolite and nitrification inhibitor (NI) are widely used during composting and land application for nitrogen conservation, respectively. Three composting reactors (A-the control, $\mathrm{B}$ - natural zeolite addition, and C-3,4-dimethylpyrazole phosphate (DMPP) addition) were established to investigate the influence of NI and natural zeolite addition on organics degradation and nitrogen transformation during sludge composting conducted at the lab scale. The results showed that, in comparison with the control, natural zeolite addition accelerated organics degradation and the maturity of sludge compost was higher, while the DMPP addition slowed down the degradation of organic matters. Meanwhile, the nitrogen transformation functional genes including those responses for nitrification (amoA and nxrA) and denitrification (narG, nirS, nirK, and nosZ) were quantified through quantitative PCR (qPCR) to investigate the effects of natural zeolites and DMPP addition on nitrogen transformation. Although no significant difference in the abundance of nitrogen transformation
\end{abstract}

Responsible editor: Philippe Garrigues

Electronic supplementary material The online version of this article (doi:10.1007/s11356-015-5326-5) contains supplementary material, which is available to authorized users.

Yuansong Wei

yswei@rcees.ac.cn

1 State Key Joint Laboratory of Environmental Simulation and Pollution Control, Research Center for Eco-Environmental Sciences, Chinese Academy of Sciences, Beijing 100085, China

2 University of Chinese Academy of Sciences, Beijing 100049, China

3 School of Safety and Environmental Engineering, Capital University of Economics and Business, Beijing 100070, China functional genes was observed between treatments, addition of both natural zeolite and DMPP increases the final total nitrogen content by $48.6 \%$ and $23.1 \%$, respectively. The ability of natural zeolite for nitrogen conservation was due to the absorption of $\mathrm{NH}_{3}$ by compost, and nitrogen conservation by DMPP was achieved by the source reduction of denitrification. Besides, it was assumed that the addition of natural zeolite and DMPP may affect the activity of these genes instead of the abundance.

Keywords Sewage sludge Composting $\cdot$ Natural zeolite . Nitrification inhibitor (NI) $\cdot 3$,4-Dimethylpyrazole phosphate (DMPP) · Nitrogen transformation functional genes

\section{Introduction}

In China, with the development of urbanization and industrialization, high amounts of sludge produced in biological wastewater treatment have been a great challenge and raised significant concerns. Total sludge production in China had an average annual growth of $13 \%$ from 2007 to 2013, and 6.25 million tons dry solids were produced in 2013 (Yang et al. 2015). Due to strict legal regulations, land shortages, rising costs, and public concern, sludge reduction, stabilization, and recycling of sludge become more and more crucial. Furthermore, treatment and disposal of sewage sludge from wastewater treatment plants (WWTPs) account for about half, even up to $60 \%$, of the total cost of wastewater treatment (Wei et al. 2003).

Sludge composting along with subsequent land application is a promising method for sludge resource utilization. In this process, organic matter is transformed into mature compost (stable and pathogen-free product) which is then used as a soil additive (Villaseñor et al. 2011). This may be the least energy 
consuming and the most cost-effective means of sludge disposal or utilization. However, in order to enhance the agronomic value of this product and reduce atmospheric pollution, nitrogen conservation should be achieved. During sludge composting, nitrogen loss is mainly caused by microbial activity involved in decomposition of nitrogenous material, nitrification, and denitrification (Bernal et al. 1996; Roig et al. 2001). The high ammonia emissions from sewage sludge composting due to the decomposition of nitrogenous material (proteins and amino acids) frequently occur at the thermophilic stage, and the characteristic low initial $\mathrm{C} / \mathrm{N}$ ratio of the sludge exacerbates this (De Guardia et al. 2008; Liang et al. 2006). The emissions of $\mathrm{NH}_{3}$, which is one of the principal malodorous compounds produced in sludge composting, can also cause nitrogen loss and acidification (Shen et al. 2011). Besides, even $\mathrm{NH}_{3}$ emissions were properly controlled, substantial amounts of nitrogen can instead be lost as elemental nitrogen $\left(\mathrm{N}_{2}\right)$ or nitrous oxide $\left(\mathrm{N}_{2} \mathrm{O}\right)$ gases via nitrification and denitrification (Szanto et al. 2007), and $\mathrm{N}_{2} \mathrm{O}$ is notorious for its great global warming potential of about 300 times in comparison with $\mathrm{CO}_{2}$ (Philippot et al. 2011). Thus, losses of $\mathrm{NH}_{3}, \mathrm{~N}_{2}$, and $\mathrm{N}_{2} \mathrm{O}$ must be controlled during sludge composting to enhance the agronomic value of the compost and reduce atmospheric pollution.

The addition of natural zeolite into sewage sludge can ensure the $\mathrm{NH}_{3}$ retention and provide several benefits during the composting process. Natural zeolite is a kind of mineral with an open reticular structure which allows the entrapment or release of various cations as a consequence of cation exchange reactions and adsorption (Venglovsky et al. 2005). The ability of natural zeolite to the retention of $\mathrm{NH}_{3}$ during sludge composting has been widely investigated (Bernal et al. 1993; Venglovsky et al. 2005; Villaseñor et al. 2011; Zuokaite and Zigmontiene 2013), and several influences of natural zeolite including increasing sludge porosity (Stylianou et al. 2008), affecting both its temperature and moisture (Venglovsky et al. 2005) and reducing heavy metals concentrations (Villaseñor et al. 2011), have been demonstrated. However, there is still little information on organics degradation during sludge composting after natural zeolite addition. Furthermore, although nitrogen transformation has been widely investigated after natural zeolite addition, the microbial mechanisms behind this and the role of functional genes involving nitrification and denitrification functional genes are still unclear.

Nitrification inhibitors (NIs) have been widely used and investigated as a useful agricultural practice for the nitrogen conservation along with land application of organic and inorganic fertilizers (Menéndez et al. 2012; Ruser and Schulz 2015). NIs are natural or synthetic compounds that inhibit the microbial oxidation of $\mathrm{NH}_{4}^{+}-\mathrm{N}$ to $\mathrm{NO}_{2}{ }^{-} \mathrm{N}$, the first step of the nitrification process, and thus reducing nitrogen loss in the form of $\mathrm{N}_{2}$ or $\mathrm{N}_{2} \mathrm{O}$ caused by denitrification (Yang et al.
2013), in which $\mathrm{NO}_{3}{ }^{-}{ }^{-} \mathrm{N}$ and $\mathrm{NO}_{2}{ }^{-}-\mathrm{N}$ are the sources of nitrogen and nitrogen leaching (Yu et al. 2007; Yu et al. 2014). 3,4-Dimethylpyrazole phosphate (DMPP) is one of the most highly effective NIs (Weiske et al. 2001; Zerulla et al. 2001). Experiments have been conducted to investigate the effects of DMPP addition on nitrogen transformation (Yu et al. 2007), plant productivity (Yu et al. 2014), nitrogen transformation functional genes (Kleineidam et al. 2011; Florio et al. 2014), and chemical parameters (Barneze et al. 2014) in soil. Moreover, it has been demonstrated that the applications of DMPP to animal manure can reduce soil $\mathrm{N}_{2} \mathrm{O}$ emissions (Weiske et al. 2001; Menéndez et al. 2012). However, there is still no information on the degradation of organics after DMPP addition. Besides, as far as we know, previous studies focused on addition of DMPP to organic fertilizers for land application, while DMPP addition may also conserve the nitrogen during sludge composting, and this deserves to be elucidated.

Thus, in this study, three composting reactors including A (the control), B (natural zeolite addition), and C (DMPP addition) were built to investigate the influence of natural zeolite and NI (DMPP) on organics degradation and nitrogen transformation of sludge composting. The evolution of organics degradation during sludge composting was mainly demonstrated through three-dimensional excitation-emission matrix spectroscopy (EEM) analysis. Previous studies have demonstrated that $\mathrm{NH}_{3}$ emissions mainly happened at earlier stage of sludge composting (Szanto et al. 2007; Maulini-Duran et al. 2013); thus, $\mathrm{NH}_{3}$ emissions were determined before entering into the maturation phase. The abundance of key functional nitrogen transformation genes involved in microbial nitrification (amoA, nxrA) and denitrification (narG, nirS, nirK, and nosZ) was determined using quantitative PCR (qPCR). The main objectives of this study were to (1) investigate the effects of natural zeolite and DMPP addition on organics degradation and nitrogen transformation during sludge composting, (2) evaluate whether alterations in the abundance among the different nitrogen transformation functional genes occurred after natural zeolite and DMPP addition, (3) elucidate the mechanisms of nitrogen conservation for natural zeolite and DMPP addition, and (4) provide a practical base for the nitrogen conservation for sludge composting.

\section{Materials and methods}

\section{Materials and experimental design}

Composting experiments of sewage sludge were carried out in three identical lab-scale closed cylinder reactors (numbered as A, B, and C) with forced aeration. Each reactor has a capacity of $48 \mathrm{~L}$ with the approximate height and diameter of 0.70 and $0.38 \mathrm{~m}$, respectively (Fig. 1). The reactors were made of 
Fig. 1 Schematic diagram of the lab-scale sludge composting system

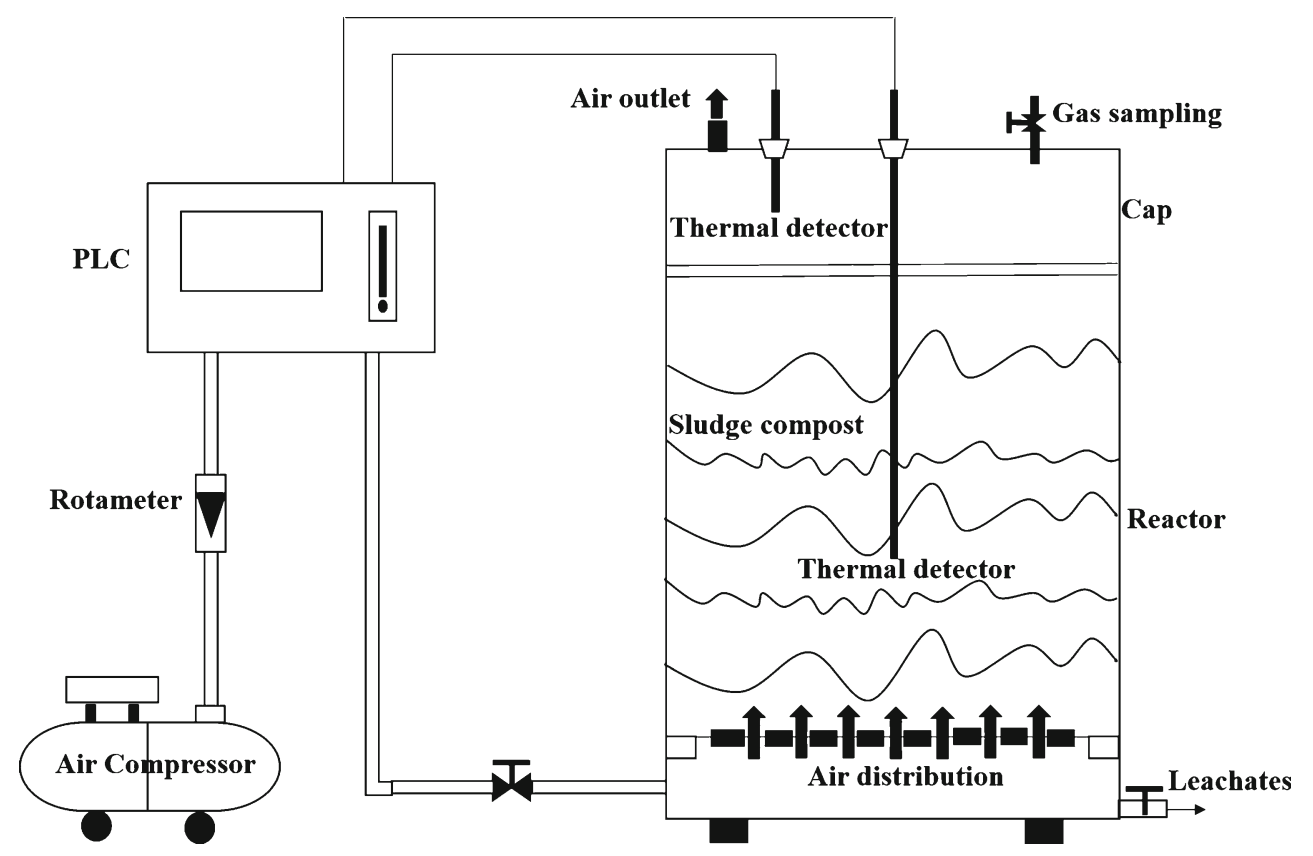

stainless steel and coated with an insulted jacket each. An air compressor (Z-550W-24L, UODI, China) was used to aerate the reactors, and a rotameter was used to control the airflow, and there were air outlets and gas sampling holes in the cap of each reactor. Two thermal detectors (KZW/P-221 Pt100, Kunlun CUHK, China) were used to monitor pile temperature. A PLC system (S7-200CN, Siemens, Germany) was built to record pile temperature once an hour and to control the aeration of each reactor. The aeration strategy was designed as follows: days $1-4,1 \mathrm{~min}$ on per $20 \mathrm{~min}^{-1}$; days 5-15, $1 \mathrm{~min}$ on per $15 \mathrm{~min}^{-1}$; and days $16-21,1 \mathrm{~min}$ on per $35 \mathrm{~min}^{-1}$, and there was no aeration during maturation phase.

The dewatered sewage sludge from Qinghe WWTP in Beijing was used in study, and the spent mushroom was used as amendment. Table 1 gives the detailed information of these materials. The commercial natural zeolite was marketed by BEIKE in China which was grinded to powder and then filtered through a 200- $\mu \mathrm{M}$-mesh sieve. The dewatered sewage sludge and the spent mushroom were mixed manually at a ratio of approximate 1:3(v/v), and then, the mixture was divided equally to the three reactors at about $45 \mathrm{~kg}$ each (wet weight). After that, natural zeolites were added at a ratio of $1 \%$ wet weight as previously suggested (Venglovsky et al. 2005; Villaseñor et al. 2011) to reactor B, and DMPP was added in the form of stock solution $(25 \%, w / v)$ to reactor $\mathrm{C}$ at a final concentration of $1 \%$ according to the total nitrogen (TN) content as usually used in land application (Yang et al. 2013; Maienza et al. 2014; Yu et al. 2014). Reactor A was treated as the control. The reactors were turned after natural zeolite and DMPP addition immediately, and after that, these three reactors were turned once 2 days before mature phase of sludge composting. There was no turn during maturation phase.

\section{Sampling and chemical analysis}

The duration of the sludge composting was set to approximately 6 months. Solid sampling was conducted throughout the composting, while $\mathrm{NH}_{3}$ sampling was conducted before the maturation phase (days 1-21). Solid and $\mathrm{NH}_{3}$ samplings were simultaneously conducted on days 1, 3, 7, 10, 13, 15, 17, and 21 , and after that, only solid sampling was conducted on days 73 and 183. Solid sampling was conducted at five positions randomly at a depth of $10-15 \mathrm{~cm}$ for each reactor, and the five sub-samples were well mixed to get a representative sample. Ammonia emissions were firstly trapped in boric acid (sampling for $30 \mathrm{~min}$ ), and then, the absorption liquid was titrated using sulfuric acid $(0.1 \mathrm{M})$ to determine the final concentration (Shen et al. 2011).

Table 1 Characteristics of raw materials of sewage sludge composting

\begin{tabular}{lll}
\hline Characteristics & Sewage sludge & Mushroom residues \\
\hline $\mathrm{pH}$ & 7.63 & 6.21 \\
Moisture content $(\%)$ & 72.23 & 26.19 \\
Organic matter $(\%)$ & 44.53 & 88.74 \\
Conductivity $(\mu \mathrm{S} / \mathrm{cm})$ & 1223 & 2413 \\
$\mathrm{TC}(\mathrm{g} / \mathrm{kg} \mathrm{DW})$ & 224.84 & 395.28 \\
$\mathrm{TN}(\mathrm{g} / \mathrm{kg} \mathrm{DW})$ & 27.69 & 26.34 \\
$\mathrm{C} / \mathrm{N}$ ratio & 8.12 & 18.92 \\
\hline
\end{tabular}


The composite solid sample was divided into two parts. One part was stored at $-20{ }^{\circ} \mathrm{C}$ until microbial analysis. The other part was freeze-dried and then grinded to pass through a $100-\mu \mathrm{M}$ mesh. Volatile solid (VS) content was obtained by determining the loss of mass after ignition at $600{ }^{\circ} \mathrm{C}$ for $5 \mathrm{~h}$. Aqueous sludge extracts obtained by shaking the samples with Milli-Q water at a ratio of 1:10 $(w / v)$ for $1 \mathrm{~h}$ were used to determine $\mathrm{pH}$. $\mathrm{C} / \mathrm{N}$ ratios were measured by Elemental Analyzer (Vario EL III, Elementar Analysensysteme GmbH, Germany) with reference material of sulfonamides (Zhong et al. 2013). As for what concerns inorganic nitrogen including $\mathrm{NH}_{4}{ }^{+}-\mathrm{N}, \mathrm{NO}_{3}{ }^{-}-\mathrm{N}$, and $\mathrm{NO}_{2}{ }^{-}-\mathrm{N}, 3.0 \mathrm{~g}$ of solid samples was extracted by $30 \mathrm{~mL}$ of $2-\mathrm{M} \mathrm{KCl}$ solution for $1 \mathrm{~h}$. The extracts were then filtered through $0.45-\mu \mathrm{m}$ membrane filters. The filtrates were then used to determine the concentrations of inorganic nitrogen; the concentrations of $\mathrm{NH}_{4}{ }^{+}-\mathrm{N}$ and $\mathrm{NO}_{2}{ }_{-}^{-}$ $\mathrm{N}$ were analyzed by the colorimetric method, while the $\mathrm{NO}_{3}{ }^{-}-$ $\mathrm{N}$ was measured by using the ultraviolet spectrophotometric method. To determine concentrations of dissolved organic carbon (DOC), 3.0-g solid sample was extracted by $30 \mathrm{~mL}$ of Milli-Q water for $24 \mathrm{~h}$ and filtered by $0.45-\mu \mathrm{m}$ membrane. The filtrates were used to determine DOC by a total organic carbon (TOC) analyzer (Shimadzu TOC-5000, Japan). Meanwhile, the filtrates were diluted in the same time and used for EEM analysis of dissolved organic matter (DOM) as described previously (Zhang et al. 2015).

\section{DNA extraction}

The solid samples on days 1, 3, 13, 21, 73, and 183 involving the four phases (heating, thermophilic, cooling, and maturation) were chosen for further qPCR analysis. DNA extraction from each solid sample $(0.5 \mathrm{~g})$ was conducted using FAST DNA extraction Kit (MP Biomedicals, USA) according to the manufacturer's instructions. Extracted genomic DNA was detected and quantified using $1 \%$ agarose gel electrophoresis and NanoDrop 2000 (Thermo Scientific, USA), respectively, and then stored at $-20{ }^{\circ} \mathrm{C}$ until use.

\section{Quantitative PCR}

Six nitrogen transformation functional genes including nitrification (amoA, nxrA) and denitrification (narG, nirS, nirK, and nos $Z$ ) and bacterial $16 \mathrm{~S}$ ribosomal RNA (rRNA) were quantified. These genes involved every key step in nitrogen removal for waste treatment. The plasmids containing these specific genes were manufactured by Zhejiang Tianke Biotechnology Company (Zhejiang, China). The standard plasmids were diluted to yield a series of tenfold concentrations and subsequently used for the establishment of qPCR standard curves. The $25-\mu \mathrm{L}$ PCR reaction mixtures contained $12.5 \mu \mathrm{L}$ SYBR Green qPCR SuperMix-UDG with Rox (Invitrogen, USA), $0.5 \mu \mathrm{L}$ each of $10 \mu \mathrm{M}$ forward and reverse primers, $10.5 \mu \mathrm{L}$
DNA-free water, and $1.0 \mu \mathrm{L}$ standard plasmid or DNA extract. The thermo cycling steps for qPCR amplification were as follows: (1) $50{ }^{\circ} \mathrm{C}, 2 \mathrm{~min}$; (2) $95^{\circ} \mathrm{C}, 5 \mathrm{~min}$; (3) $95^{\circ} \mathrm{C}, 20 \mathrm{~s}$; (4) annealing temperature, $30 \mathrm{~s}$; (5) $72{ }^{\circ} \mathrm{C}, 31 \mathrm{~s}$; (6) plate read, go to (3) (5), 39 more times; and (7) melt curve analysis: $60{ }^{\circ} \mathrm{C}$ to $95^{\circ} \mathrm{C}, 0.2{ }^{\circ} \mathrm{C} / \mathrm{read}$. The reaction was conducted using an ABI Real-time PCR system 7500 (ABI, USA). The specificity was assured by the melting curves and gel electrophoresis. Each gene was quantified in triplicate with a standard curve and negative control. The primers, annealing temperature used in qPCR, and the corresponding amplification efficiencies were summarized in Tables 2 and $\mathrm{S} 1$.

\section{Data analysis}

Statistical calculations and data analysis were performed with the SPSS 18.0 statistical software package (IBM, USA) and Origin 9.0 (OriginLab, USA). The degradation of volatile solid (VS) was fit to a first-order kinetic model (ExpDec1) using Origin 9.0. The EEM analysis was visualized by Origin 9.0, and the set levels were normalized according to TOC concentrations of each sample to compare the changes of organics in the form of its ratios in the sample. One-way ANOVA analysis was conducted to determine if the evolution of the parameters concerned in this study between different treatments were statistically significant. Spearman rank correlations were used to assess the association between different parameters. Any difference where $p$ value $>0.05$ was not considered to be statistically significant. Principal component analysis (PCA) was conducted using Canoco 5.0 (Microcomputer Power, USA).

\section{Results and discussion}

\section{Pile temperature and $\mathrm{pH}$ value}

The pile temperature and $\mathrm{pH}$ changed significantly over the sludge composting period, and the additions of both natural zeolite and DMPP have certain impacts on the pile temperature and $\mathrm{pH}$ (Fig. 2a). Pile temperature is the principal parameter used to indicate the performance of composting (Wei et al. 2000). According to one-way ANOVA analysis, natural zeolite and DMPP addition had a significant influence $(p=0.018$ and 0.002 , respectively) on the pile temperature development during sludge composting. Although all treatments reflected the typical pile temperature as for many composting processes including the heating, thermophilic, cooling, and mature phases, the pile temperature pattern for reactor C (DMPP addition) was significantly different from the others, with the maximum pile temperature for $\mathrm{A}, \mathrm{B}$, and $\mathrm{C}$ of 56,56 , and $45{ }^{\circ} \mathrm{C}$, respectively. The pile temperature of reactor $\mathrm{C}$ was always much lower than those of $\mathrm{A}$ and $\mathrm{B}$ during the heating and thermophilic phases. The heating phase lasted for 5 days 
Table 2 The primer sequences, expected amplicon size, and annealing temperature for each target gene considered in this study

\begin{tabular}{|c|c|c|c|c|}
\hline Target gene & Primer sequence $\left(5^{\prime}-3^{\prime}\right)$ & Size (bp) & Annealing temp. $\left({ }^{\circ} \mathrm{C}\right)$ & Reference \\
\hline amoA & $\begin{array}{l}\text { amoA-1F: GGGGTTTCTACTGGTGGT } \\
\text { amoA-2R: CCCCTCKGSAAAGCCTTCTTC }\end{array}$ & 491 & 61 & (Rotthauwe and Witzel 1997) \\
\hline$n x r A$ & $\begin{array}{l}\text { F1norA: CAGACCGACGTGTGCGAAAG } \\
\text { R1norA: TCYACAAGGAACGGAAGGTC }\end{array}$ & 332 & 58 & (Zhi and Ji 2014) \\
\hline $\operatorname{nar} G$ & $\begin{array}{l}\text { 1960m2f: TAYGTSGGGCAGGARAAACTG } \\
\text { 2050m2r: CGTAGAAGAAGCTGGTGCTGTT }\end{array}$ & 110 & 50 & (López-Gutiérrez et al. 2004) \\
\hline $\operatorname{nir} S$ & $\begin{array}{l}\text { nirScd3aF: GTSAACGTSAAGGARACSGG } \\
\text { nirSR3cd: GASTTCGGRTGSGTCTTGA }\end{array}$ & 425 & 58 & (Lu et al. 2014) \\
\hline nirK & $\begin{array}{l}\text { nirK1F: GGMATGGTKCCSTGGCA } \\
\text { nirK5R: GCCTCGATCAGRTTRTGG }\end{array}$ & 515 & 56 & (Braker et al. 1998) \\
\hline $\operatorname{nos} Z$ & $\begin{array}{l}\text { nosZ2F: CGCRACGGCAASAAGGTSMSSGT } \\
\text { nosZ2R: CAKRTGCAKSGCRTGGCAGAA }\end{array}$ & 264 & 55 & (Henry et al. 2006) \\
\hline 16S rRNA & $\begin{array}{l}\text { 1369F: CGGTGAATACGTTCYCGG } \\
\text { 1492R: GGWTACCTTGTTACGACTT }\end{array}$ & 128 & 55 & (Suzuki et al. 2000) \\
\hline
\end{tabular}

and the thermophilic phase for 12 days which sufficed to ensure devitalization of potentially present pathogens. When the compost entered into the cooling and mature phase, the pile temperature was close to the ambient (about $27^{\circ} \mathrm{C}$ ) and the pile temperature of $\mathrm{C}$ was a little higher than those of $\mathrm{A}$ and $\mathrm{B}$ (data not shown). This indicated that the addition of DMPP influenced the microbial activity, which was in accordance with a microcosm study of cattle effluent and DMPP added to soil (Florio et al. 2014). However, the relatively long cooling phase and slightly higher temperature during mature phase indicated that DMPP just inhibited the microbial activity and did not killed the microbes. This was due to the properties of NI, which is a bacteriostatic agent rather than a bactericide (O'Callaghan et al. 2010). Furthermore, the natural zeolite addition led to lower temperature during the cooling and mature phase in comparison with the control and slightly higher pile temperature during the thermophilic stage. This was due to the bulking effect of natural zeolite which enhanced radiation of the heat to the atmosphere. A similar effect has been reported previously (Villaseñor et al. 2011).

The $\mathrm{pH}$ value is one of the crucial characteristics of composting. In all of the experiments, the $\mathrm{pH}$ ranged from 6.09 to 8.79 , increased significantly at the heating phase, and then changed a little until the end (Fig. 2b). This was due to the degradation of protein-like substances which released amounts of $\mathrm{NH}_{3}$ (Fig. 4b). Reactor B (natural zeolite
Fig. 2 Evolution of pile temperature (a, the median of each day), $\mathrm{pH}(\mathbf{b})$, volatile solid (c, VS), TOC (d), and C/N (e) ratio during sludge composting
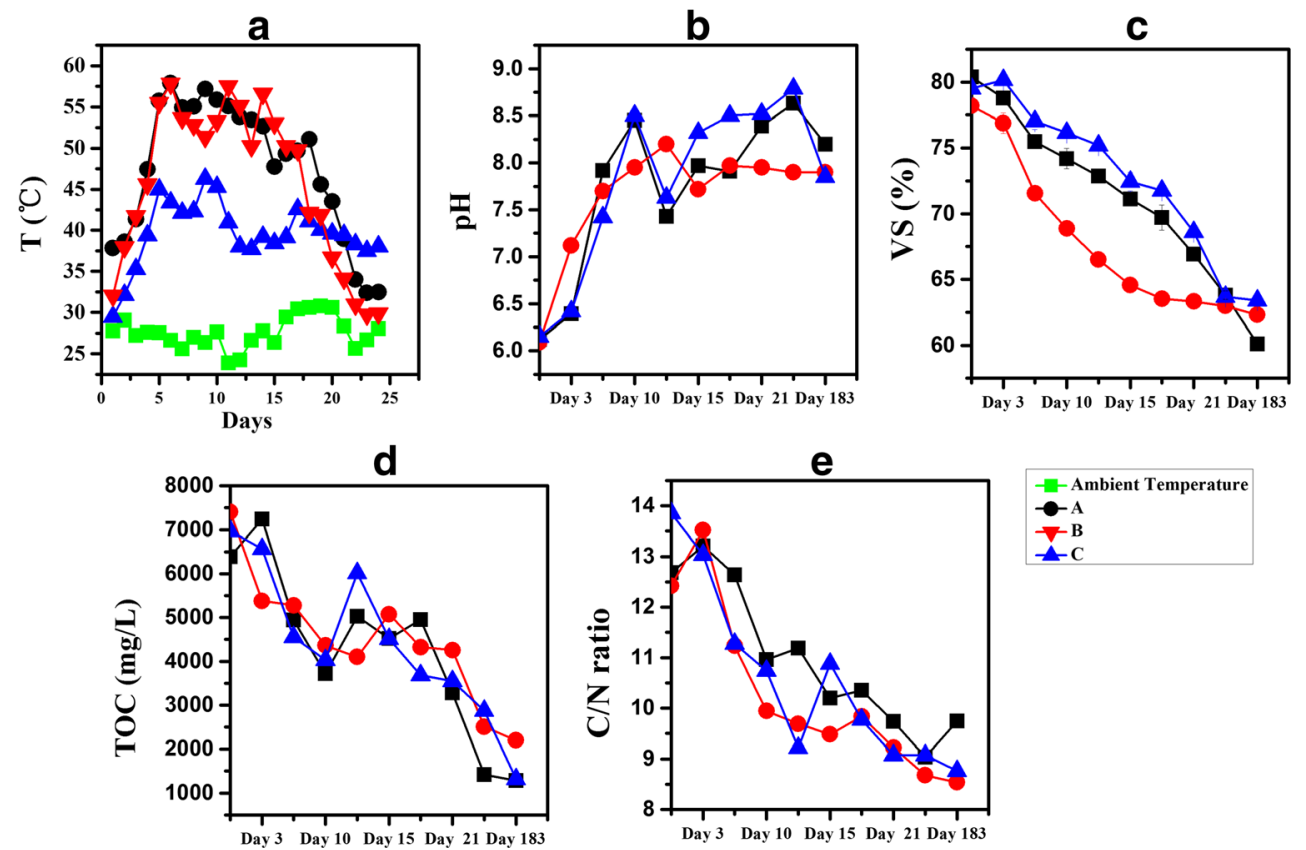

- Ambient Temperature $-\mathrm{A}$
$-\mathrm{B}$
$-\mathrm{C}$ 
addition) appeared to acidify the compost compared with reactor $\mathrm{A}$, and there was much difference on the profiles of $\mathrm{pH}$ between reactors $\mathrm{A}$ and $\mathrm{B}$. The final $\mathrm{pH}$ of $\mathrm{A}$ and $\mathrm{B}$ was 8.20 and 7.90, respectively. Similar $\mathrm{pH}$ profiles after natural zeolite addition were also reported by Turan and Ergun (2008) and Villaseñor et al. (2011), and they both found that $\mathrm{pH}$ decreased due to the natural zeolite addition to the municipal solid waste composting. As for reactor $\mathrm{C}$ (DMPP addition), the $\mathrm{pH}$ profile was similar to reactor A.

\section{Organics degradation}

According to the changes of volatile solid (VS) (Fig. 2c), TOC (Fig. 2d), C/N ratio (Fig. 2e), and EEM spectra (Fig. 3), the organics degradation changed much due to the addition of natural zeolites and DMPP. VS, TOC, and $\mathrm{C} / \mathrm{N}$ ratio all decreased along with sludge composting. However, the profiles of VS were quite different between treatments. The biodegradation of organics revealed by VS was improved by the addition of natural zeolite, while inhibited by DMPP addition (Fig. 2c). The degradation of VS fitted the first-order kinetic model (all $R^{2}>0.96, p<0.0001$ ), and the $\mathrm{t}_{1 / 2}$ reflected the order of the degradation rate of VS which was $\mathrm{B}\left(t_{1 / 2}=8.69\right)>\mathrm{A}$ $\left(t_{1 / 2}=20.68\right)>\mathrm{C}\left(t_{1 / 2}=23.42\right)$. Previous studies also demonstrated that the degradation of organics can be accelerated by the natural zeolite addition during sewage sludge composting (Villaseñor et al. 2011). Also, Stylianou et al. (2008) found that larger amounts of organics were removed when $20 \%$ zeolites were added to the sludge composting. The $\mathrm{C} / \mathrm{N}$ ratio of reactor B also decreased more quickly. Furthermore, the inhibition of DMPP for the biodegradation of organics was in accordance with the profiles of temperature development for reactor $\mathrm{C}$; that is, the slower the organics degradation, the lower the temperature.

To investigate changes in the components of compost, we further conducted the EEM analysis. Besides, the concentrations of TOC changed significantly during sludge composting (Fig. 2d), while EEM analysis was done in the same diluted times. Thus, in order to compare changes in the components at the same TOC concentrations, the set levels were normalized according to the TOC concentrations of each sample (Fig. 3). Following Chen et al. (2003), the EEM spectra can be divided into five regions depending on the wavelengths of the organics as follows: regions I and II, aromatic proteins; region III, fulvic acid-like substances; region IV, soluble microbial by-product-like substances; and region V, humic acid-like

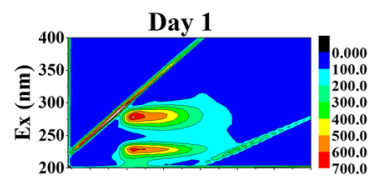

a
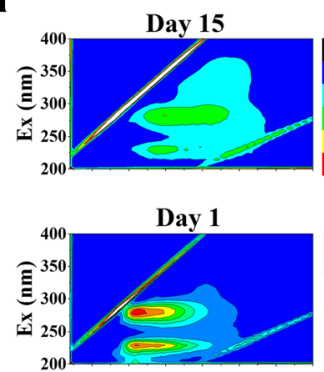

b

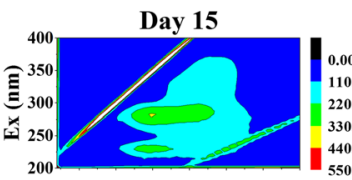

Day 1

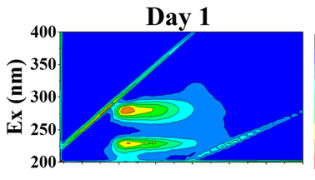

C

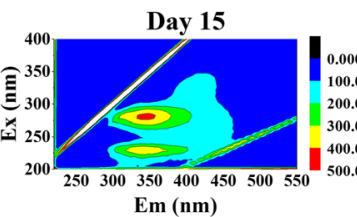

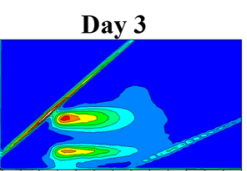

Day 17

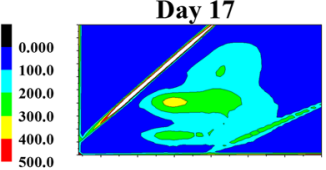

Day 3

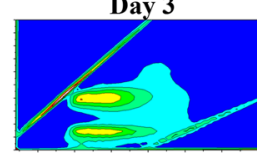

Day 17

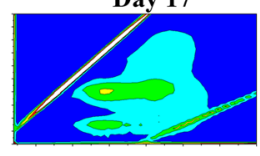

Day 3
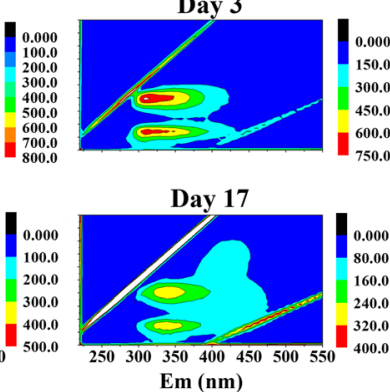

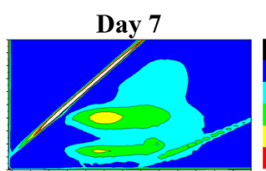

Day 21

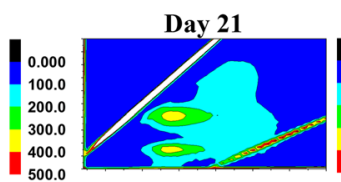

Day 7
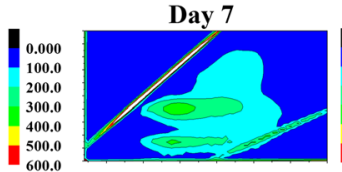

Day 21

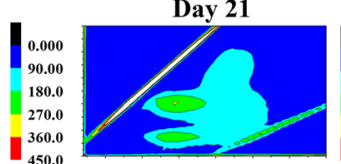

Day 7

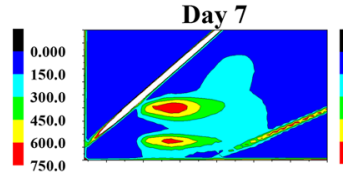

Day 21

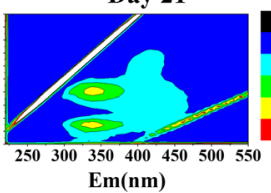

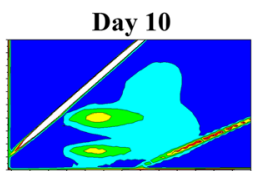

Day 73

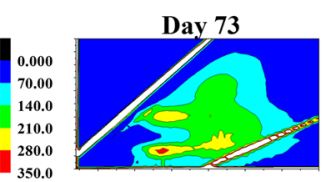

Day 10
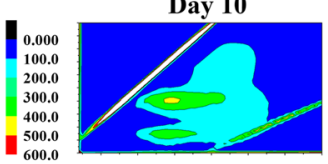

Day 73
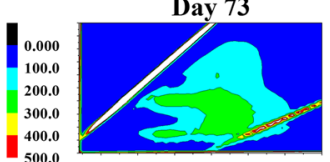

Day 10
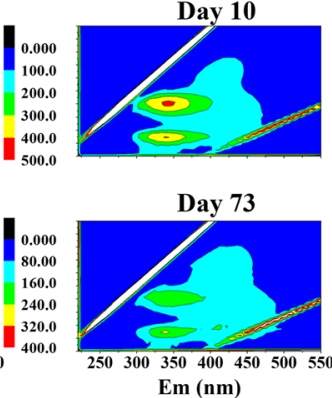

Day 73

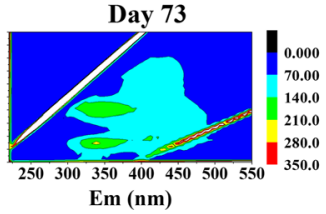

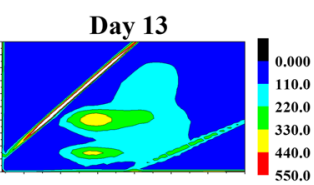

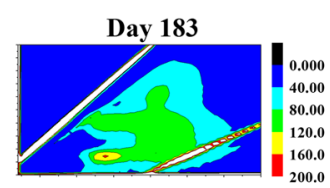

Day 13

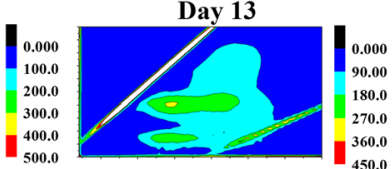

Day 183

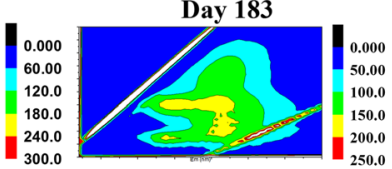

Day 13

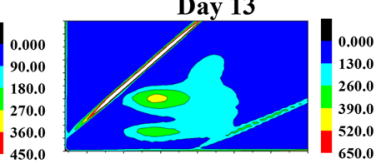

Day 183

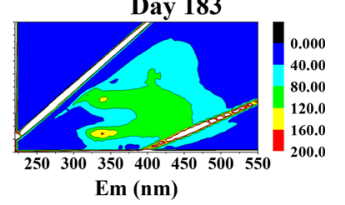

Fig. 3 Evolution of EEM spectra during sludge composting. The set levels were normalized according to TOC concentrations of each sample 
substances. The details of the regions were shown in supporting information (Fig. S1).

Dissolved organic matter (DOM) is the main active organic fraction and is more easily utilized by microorganisms relative to solid-phase organics; the chemical composition and structure of DOM have been widely investigated in composting in relation to the evaluation of the quality of the composting product (Straathof and Comans 2015). As for the different treatments of sludge composting, the fluorescent intensity of EEM spectra all moved from regions I, II, and IV to the III and V. These profiles were usually observed for composting (Wang et al. 2014; Straathof and Comans 2015), and the enhancement of the regions III and V was generally considered as the maturity of the compost. Although the final fluorescent intensity of EEM spectra (day 183) was concentrated at regions III and V for all treatments, the intensity of reactor B was obviously higher than others (Fig. 3, day 183). This indicated that the natural zeolite addition led to higher compost maturity. Besides, the evolution of the EEM spectra differed a lot between treatments, which reflected the degradation rate of DOM and the microbial activity during sludge composting. The fluorescence intensity on day 1 was mainly concentrated in regions II and IV, which suggested that aromatic proteins and microbial by-products were the major fluorescent DOM in all treatments. As sludge composting progressed, the aromatic proteins and microbial by-products were depleted, and fulvic- and humic-acid like substances appeared, as reflected by regions III and V appeared. The fluorescent signal shifted to regions III and $\mathrm{V}$ indicated that the constituents of the DOM were very well transformed during sludge composting. However, the time course of this change differed a lot between treatments (Fig. 3). The fluorescence intensity of regions II and IV almost disappeared on day 7 for reactor $\mathrm{B}$, while at day 15 for $\mathrm{A}$ and for $\mathrm{C}$, the fluorescence intensity was still obvious until the end of the cooling phase (day 21). Thus, the order of the degradation rate of DOM during sludge composting in this study was as follows: $\mathrm{B}>\mathrm{A}>\mathrm{C}$. The slowest degradation rate of DOM for reactor $\mathrm{C}$ was also in accordance with its temperature and VS profiles, and the fastest degradation for reactor B could be reflected by the VS pattern. Together, natural zeolite addition availed the degradation of organics and the maturity of the compost was higher, while DMPP addition slowed down the degradation.

\section{Nitrogen transformation}

Figure 4 shows the evolution of nitrogen-relevant transformation substances including $\mathrm{TN}, \mathrm{NH}_{3}$ emissions, $\mathrm{NH}_{4}{ }^{+}-\mathrm{N}$,
$\mathrm{NO}_{2}{ }^{-}-\mathrm{N}$, and $\mathrm{NO}_{3}{ }^{-}-\mathrm{N}$ during sludge composting in different treatments. Significant changes in nitrogen transformation between treatments were observed, and the natural zeolite and DMPP both showed the potential of nitrogen conservation during sludge composting. As reflected by Fig. $4 a$, total nitrogen $(\mathrm{TN})$ increased along with composting due to the concentration effects and the final concentration of TN (dry weight (DW)) was 2.47, 3.67, and $3.04 \%$ for reactors A, B and C, respectively, which indicated that natural zeolite and DMPP addition during sludge composting could increase the TN by 48.6 and $23.1 \%$, respectively. The greatest nitrogen conservation of natural zeolite could be mainly explained by the different profiles of the $\mathrm{NH}_{3}$ flux between treatments. The results shown in Fig. 4b clearly illustrate the retention of $\mathrm{NH}_{3}$ by natural zeolite. The pattern of $\mathrm{NH}_{3}$ flux in this study was typical for sludge composting, and the $\mathrm{NH}_{3}$ emissions mainly happened on days 3-7 at the heating and thermophilic stage. However, the $\mathrm{NH}_{3}$ flux of reactor B was significantly lower than that of $\mathrm{A}$ and $\mathrm{C}$, and the peak $\mathrm{NH}_{3}$ flux was 1.87 , 1.10 , and $1.79 \mathrm{mg} \mathrm{m}^{-2} \mathrm{~h}^{-1}$, respectively. The absorption of $\mathrm{NH}_{3}$ by natural zeolite was generally observed (Bernal et al. 1993; Venglovsky et al. 2005; Stylianou et al. 2008; Bernal et al. 2009). As an effect of the delay of nitrification by NI, reactor $\mathrm{C}$ showed higher concentrations of $\mathrm{NH}_{4}{ }^{+}-\mathrm{N}$ (Fig. 4c), which indicated that DMPP addition should have increased the $\mathrm{NH}_{3}$ emissions. However, DMPP addition had little effect on $\mathrm{NH}_{3}$ emissions in comparison with the control (reactor A). This was due to the lowest temperature development for reactor $\mathrm{C}$ which was the key parameter for $\mathrm{NH}_{3}$ emissions during composting.

The higher concentrations of $\mathrm{NH}_{4}{ }^{+}-\mathrm{N}$ and lower concentrations of $\mathrm{NO}_{2}{ }^{-}-\mathrm{N}$ and $\mathrm{NO}_{3}{ }^{-} \mathrm{N}$ for reactor $\mathrm{C}$ throughout the composting shown in Fig. 4 indicated the inhibitory effect of DMPP on the ammonia-oxidizing bacteria (AOB). The results were also confirmed by previous study concerning the DMPP land application with organic fertilizer (Yang et al. 2013). It was assumed that the inhibition of the AOB by NI directly decreased the nitrification rate and it significantly reduced the concentrations of $\mathrm{NO}_{2}{ }^{-}-\mathrm{N}$ and $\mathrm{NO}_{3}{ }^{-}-\mathrm{N}$ (Fig. 4d, e) which serve as substrate for denitrification. Hence, the main pathways of $\mathrm{N}_{2}$ and $\mathrm{N}_{2} \mathrm{O}$ production were blocked or their source strength was at least decreased, although they were not monitored in this study. This explained the nitrogen conservation for DMPP addition during sludge composting. While, the natural zeolite addition had little effect on the evolution of concentrations of $\mathrm{NH}_{4}{ }^{+}-\mathrm{N}$ and $\mathrm{NO}_{2}{ }^{-} \mathrm{N}$ but not of $\mathrm{NO}_{3}{ }^{-}-\mathrm{N}$. The concentrations of $\mathrm{NO}_{3}{ }^{-}-\mathrm{N}$ at maturation phase all increased; however, reactor B increased significantly in comparison with $\mathrm{A}$ and $\mathrm{C}$ due to the bulking effects of the zeolites, and the final concentration was $2.12 \mathrm{mg} / \mathrm{g} \mathrm{DW}, 4.01 \mathrm{mg} / \mathrm{g} \mathrm{DW}$, and $2.56 \mathrm{mg} / \mathrm{g}$ DW for reactors A, B, and C, respectively. In summary, the potential nitrogen conservation of natural zeolite mainly contribute to its ability of $\mathrm{NH}_{3}$ absorption, while for 

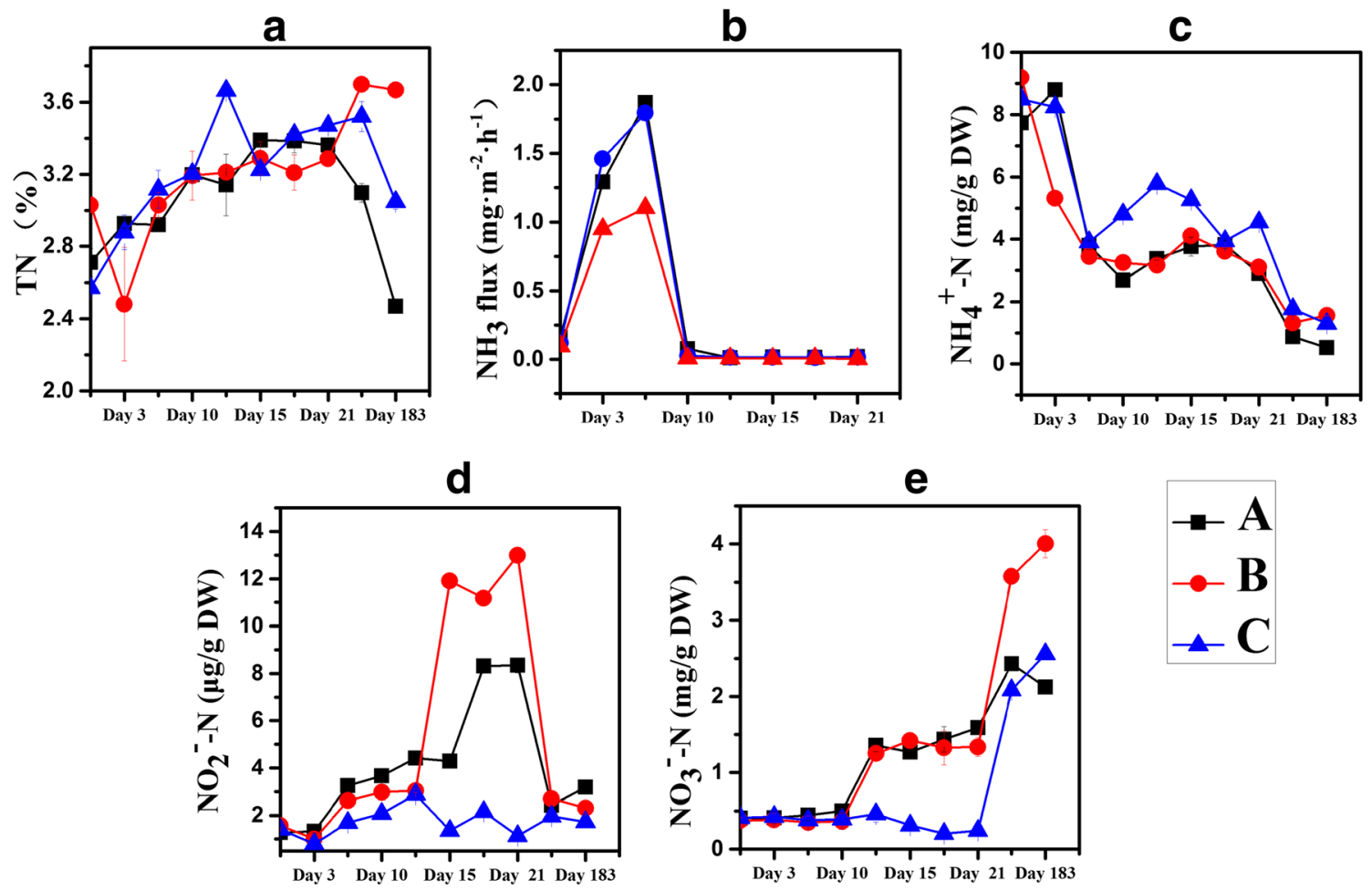

Fig. 4 The nitrogen transformation during sludge composting in different treatments reflected by total nitrogen $(\mathrm{TN})(\mathbf{a}), \mathrm{NH}_{3}$ flux $(\mathbf{b}), \mathrm{NH}_{4}{ }^{+}-\mathrm{N}(\mathbf{c})$, $\mathrm{NO}_{2}{ }^{-}-\mathrm{N}(\mathbf{d})$, and $\mathrm{NO}_{3}{ }^{-}-\mathrm{N}(\mathbf{e})$

DMPP, it was the reduction of $\mathrm{N}_{2}$ and $\mathrm{N}_{2} \mathrm{O}$ emissions caused by its nitrification inhibitory effect.

\section{Evolution of the abundance of nitrogen transformation functional genes}

The gene copies of nitrification ( $a m o A$ and $n x r A$ encoding for bacterial ammonia monooxygenase and nitrite oxidoreductase, respectively) and denitrification genes (nar G, nirK, nirS, and nos $Z$ encoding for membrane-bound nitrate reductase, copper nitrite reductase, cd1 nitrite reductase, and nitrous oxide reductase, respectively) were determined in different treatments throughout the experiments at the heating, thermophilic, cooling, and maturation phase of sludge composting. The gene copies changed a lot over the composting period (Fig. 5). The nitrification genes ( $a m o A$ and $n x r A$ ) changed little before maturation phase and increased significantly at the maturation phase, while denitrification genes (narG, nirS, nirK, and $n o s Z$ ) increased gradually along with sludge composting (Fig. 5). There were significantly negative spearman correlations between temperature and $\operatorname{amo} A(p=0.004)$ and $n x r A$ ( $p=$ 0.03 ). The little changes in amo $A$ and $n x r A$ could be due to the inhibition of nitrifiers at higher temperature as confirmed by Roig et al. (2001) who found that nitrification occurred only when the temperature of the mixtures fell below $40{ }^{\circ} \mathrm{C}$, while denitrification was well ongoing before maturation phase, as reflected by the changes of denitrification genes.

The abundance of bacterial amoA ranged from $1.49 \times$ $10^{5}$ to $2.61 \times 10^{8}$ gene copies $\mathrm{g}^{-1} \mathrm{DW}$ and reached the peak at day 73 . There were significant differences between treatments at day 13 and 21 at the thermophilic phase, when nitrification activity was severely inhibited, while there was almost no difference at maturation phase. This indicated that natural zeolites and DMPP addition had no significant effects on the abundance of amo $A$ at maturation phase. Natural zeolites showed the physical effects on nitrogen conservation; thus, the abundance of amoA changed little, while DMPP addition should have shown the specific inhibition on AOB. However, the DMPP addition did not changed the abundance of amoA significantly, and the activity of nitrifiers was indeed inhibited as shown in Fig. 4 (higher $\mathrm{NH}_{4}{ }^{+}$$\mathrm{N}$ concentrations and lower $\mathrm{NO}_{2}^{-}-\mathrm{N}$ and $\mathrm{NO}_{3}{ }^{-}-\mathrm{N}$ concentrations due to DMPP addition). Concerning the effects of DMPP addition to the abundance and activity of amoA, the arguments still existed. For instance, Kleineidam et al. (2011) observed impaired abundance of AOB in soil compartments after DMPP addition, while Florio et al. (2014) found that no significant changes in amoA gene copies could be detected in soil after DMPP addition, while the transcriptional activity 


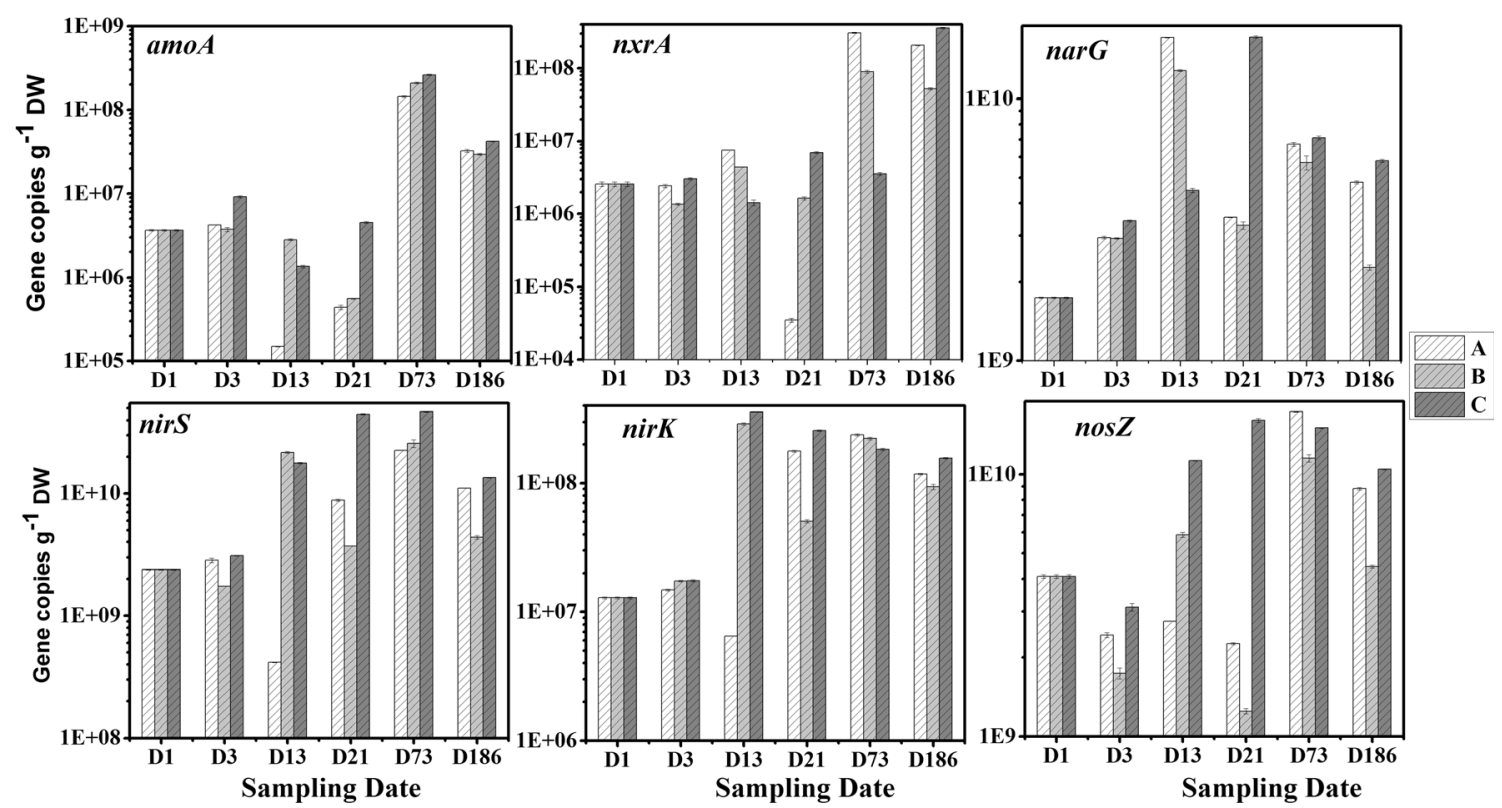

Fig. 5 Changes of gene copies of key nitrogen functional genes during sludge composting

revealed by amoA mRNA was impaired. The latter was suggested in this study. The other nitrification gene (nxrA) ranged from $3.94 \times 10^{4}$ to $3.59 \times 10^{8}$ gene copies $\mathrm{g}^{-1}$ DW. The rapidest increment occurred at days 21 to 73 for the control (reactor A). The reason for this increment cannot be elucidated in this study, and further research may be needed.

The highest gene copies of denitrification genes were all observed at the maturation phase except for $n a r G$ of reactor $\mathrm{C}$, and among these functional genes, the average abundance of nar $G$ ranged from $1.74 \times 10^{9}$ to $1.72 \times 10^{10}$ gene copies $\mathrm{g}^{-1}$ DW. Although nitrite can be reduced via either nirK gene or nirS gene, this study revealed that the abundance of nirS gene (average gene copies $\mathrm{g}^{-1} \mathrm{DW}, 1.31 \times 10^{10}$ ) was about $2 \mathrm{logs}$ higher than that of nirK gene $\left(1.24 \times 10^{8}\right.$ gene copies $\left.\mathrm{g}^{-1} \mathrm{DW}\right)$. This dominance of $\operatorname{nir} S$ gene over nirK gene was consistent throughout the sludge composting. The abundance of nos $Z$ gene ranged from $1.25 \times 10^{9}$ to $1.74 \times 10^{10}$ gene copies $\mathrm{g}^{-1}$ DW. According to the one-way ANOVA analysis, the difference of these genes was all not statistically significant between treatments, which indicated that natural zeolites and DMPP addition had little effect on the abundance of nitrogen transformation functional genes. Principal component analysis (PCA) based on the evolution of the gene copies of these nitrogen transformation functional genes shown in Fig. 6 also confirmed this indication, in which the final samples concentrated together at the initial and the final while the evolution of them maybe a little different. However, the evolution of nitrogen transformation changed a lot between treatments, and the evolution of gene copies of 16S rRNA shown in Fig. S2 also reflected that the biomass was little affected by natural zeolites and DMPP addition. Thus, we assumed that natural zeolites and DMPP addition impacted the activity but not the abundance of nitrogen transformation functional genes.

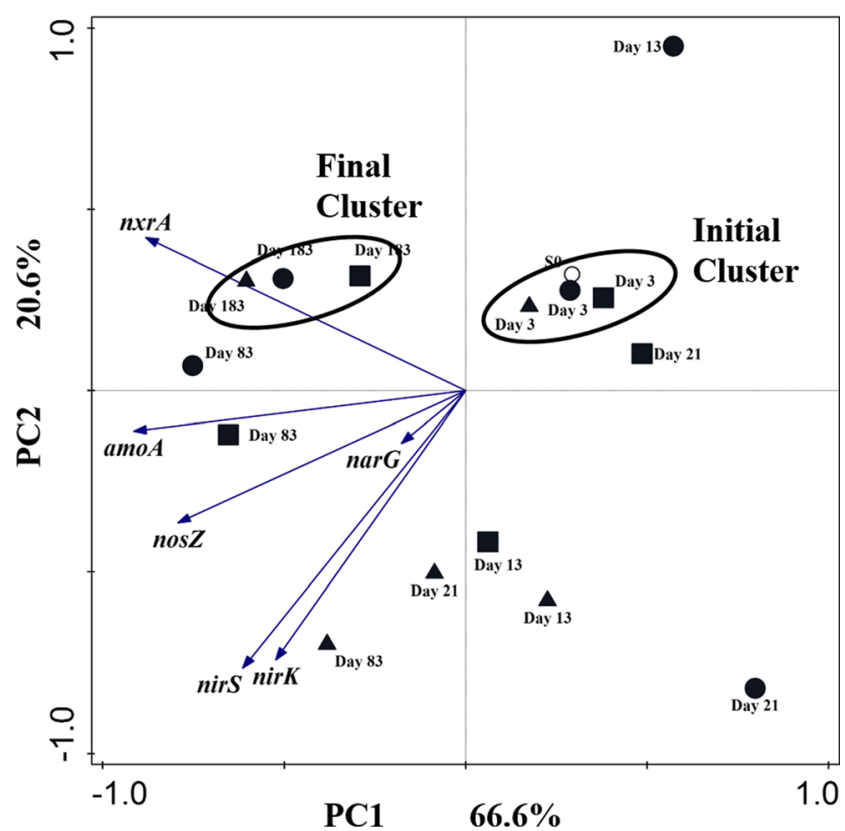

Fig. 6 Principal component analysis (PCA) based on the abundance of nitrogen transformation functional genes. Empty circle stands for the initial sample. Filled circle stands for samples from reactor A. Filled square stands for samples from reactor B. Filled triangle stands for samples from reactor $\mathrm{C}$. The initial samples and the final samples concentrated together as initial cluster and final cluster, respectively 


\section{Conclusions}

In this study, we investigated the influence of the natural zeolite and DMPP addition on organics degradation and nitrogen transformation during sludge composting. The natural zeolite addition showed the fastest degradation of organic matters, and the maturity of the compost was the highest, while DMPP addition slowed down the organic degradation demonstrated through the evolution of volatile solid (VS) and threedimensional excitation-emission matrix (EEM) analysis. Besides, the results confirmed that natural zeolite addition lessened the nitrogen loss and demonstrated that DMPP addition also can be used for nitrogen conservation, and the natural zeolite and DMPP addition could increase the TN by 48.6 and $23.1 \%$, respectively. The mechanisms for nitrogen conservation differed a lot. The natural zeolite was due to the absorption of $\mathrm{NH}_{3}$, while DMPP was the inhibitory effects of AOB, which lead to less sources for denitrification; thus, the reduction of nitrogen through $\mathrm{N}_{2}$ or $\mathrm{N}_{2} \mathrm{O}$ decreased. On the basis of the results of this study, natural zeolite and DMPP amendment to sludge composting has the potential to lessen nitrogen loss, thereby offering a potential strategy to nitrogen conservation and deliver environmental benefits.

Acknowledgments This work is supported by the National Major Science \& Technology Projects for Water Pollution Control and Management of China (2012ZX07202-005) and the National Natural Science Foundation of China (21377151).

Conflict of interest The authors declare no conflict of interest.

\section{References}

Barneze AS, Minet EP, Cerri CC, Misselbrook T (2014) The effect of nitrification inhibitors on nitrous oxide emissions from cattle urine depositions to grassland under summer conditions in the UK. Chemosphere 119C:122-129. doi:10.1016/j.chemosphere.2014.06. 002

Bernal MP, Lopez-Real JM, Scott KM (1993) Application of natural zeolites for the reduction of ammonia emissions during the composting of organic wastes in a laboratory composting simulator. Bioresour Technol 43:35-39. doi:10.1016/0960-8524(93)90079-Q

Bernal MP, Navarro AF, Roig A et al (1996) Carbon and nitrogen transformation during composting of sweet sorghum bagasse. Biol Fertil Soils 22:141-148. doi:10.1007/s003740050089

Bernal MP, Alburquerque JA, Moral R (2009) Composting of animal manures and chemical criteria for compost maturity assessment. A review. Bioresour Technol 100:5444-5453. doi:10.1016/j.biortech. 2008.11.027

Braker G, Fesefeldt A, Witzel KP (1998) Development of PCR primer systems for amplification of nitrite reductase genes (nirK and nirS) to detect denitrifying bacteria in environmental samples. Appl Environ Microbiol 64:3769-3775

Chen W, Westerhoff P, Leenheer JA, Booksh K (2003) Fluorescence excitation-emission matrix regional integration to quantify spectra for dissolved organic matter. Environ Sci Technol 37:5701-5710. doi:10.1021/es034354c
De Guardia A, Petiot C, Rogeau D, Druilhe C (2008) Influence of aeration rate on nitrogen dynamics during composting. Waste Manage 28:575-587

Florio A, Clark IM, Hirsch PR et al (2014) Effects of the nitrification inhibitor 3,4-dimethylpyrazole phosphate (DMPP) on abundance and activity of ammonia oxidizers in soil. Biol Fertil Soils 50:795807. doi:10.1007/s00374-014-0897-8

Henry S, Bru D, Stres B et al (2006) Quantitative detection of the nosZ gene, encoding nitrous oxide reductase, and comparison of the abundances of $16 \mathrm{~S}$ rRNA, narG, nirK, and nosZ genes in soils. Appl Environ Microbiol 72:5181-5189

Kleineidam K, Košmrlj K, Kublik S et al (2011) Influence of the nitrification inhibitor 3,4-dimethylpyrazole phosphate (DMPP) on ammonia-oxidizing bacteria and archaea in rhizosphere and bulk soil. Chemosphere 84:182-186. doi:10.1016/j. chemosphere.2011.02.086

Liang Y, Leonard JJ, Feddes JJR, McGill WB (2006) Influence of carbon and buffer amendment on ammonia volatilization in composting. Bioresour Technol 97: 748-761

López-Gutiérrez JC, Henry S, Hallet S et al (2004) Quantification of a novel group of nitrate-reducing bacteria in the environment by realtime PCR. J Microbiol Methods 57:399-407

Lu H, Chandran K, Stensel D (2014) Microbial ecology of denitrification in biological wastewater treatment. Water Res 64:237-254

Maienza A, Bååth E, Stazi SR et al (2014) Microbial dynamics after adding bovine manure effluent together with a nitrification inhibitor (3,4 DMPP) in a microcosm experiment. Biol Fertil Soils 50:869 877. doi:10.1007/s00374-014-0907-x

Maulini-Duran C, Artola A, Font X, Sánchez A (2013) A systematic study of the gaseous emissions from biosolids composting: raw sludge versus anaerobically digested sludge. Bioresour Technol 147:43-51. doi:10.1016/j.biortech.2013.07.118

Menéndez S, Barrena I, Setien I et al (2012) Efficiency of nitrification inhibitor DMPP to reduce nitrous oxide emissions under different temperature and moisture conditions. Soil Biol Biochem 53:82-89. doi:10.1016/j.soilbio.2012.04.026

O'Callaghan M, Gerard EM, Carter PE et al (2010) Effect of the nitrification inhibitor dicyandiamide (DCD) on microbial communities in a pasture soil amended with bovine urine. Soil Biol Biochem 42:1425-1436. doi:10.1016/j.soilbio. 2010.05.003

Philippot L, Andert J, Jones CM et al (2011) Importance of denitrifiers lacking the genes encoding the nitrous oxide reductase for $\mathrm{N} 2 \mathrm{O}$ emissions from soil. Glob Chang Biol 17:1497-1504. doi:10.1111/ j.1365-2486.2010.02334.x

Roig A, Paredes C, Bernal MP (2001) Nitrogen transformation during organic waste composting by the Rutgers system and its effects on $\mathrm{pH}, \mathrm{EC}$ and maturity of the composting mixtures. Bioresour Technol 78:301-308. doi:10.1016/S0960-8524(01)00031-1

Rotthauwe J, Witzel K (1997) The ammonia monooxygenase structural gene amoA as a functional marker: molecular fine-scale analysis of natural ammonia-oxidizing populations. Appl Environ Microbiol 63:4704-4712

Ruser R, Schulz R (2015) The effect of nitrification inhibitors on the nitrous oxide $\left(\mathrm{N}_{2} \mathrm{O}\right)$ release from agricultural soils - a review. J Plant Nutr Soil Sci 178:171-188. doi:10.1002/jpln.201400251

Shen Y, Ren L, Li G et al (2011) Influence of aeration on $\mathrm{CH}_{4}, \mathrm{~N}_{2} \mathrm{O}$ and $\mathrm{NH}_{3}$ emissions during aerobic composting of a chicken manure and high $\mathrm{C} / \mathrm{N}$ waste mixture. Waste Manag 31:33-38. doi:10.1016/j. wasman.2010.08.019

Straathof AL, Comans RNJ (2015) Input materials and processing conditions control compost dissolved organic carbon quality. Bioresour Technol 179:619-623. doi:10.1016/j.biortech.2014.12.054

Stylianou MA, Inglezakis VJ, Moustakas KG, Loizidou MD (2008) Improvement of the quality of sewage sludge compost by adding 
natural clinoptilolite. Desalination 224:240-249. doi:10.1016/j. desal.2007.06.009

Suzuki MT, Taylor LT, Delong EF, Long EFDE (2000) Quantitative Analysis of Small-Subunit rRNA Genes in Mixed Microbial Populations via $5^{\prime}$-Nuclease Assays. Appl Environ Microbiol 66: 4605-4614

Szanto GL, Hamelers HVM, Rulkens WH, Veeken AHM (2007) $\mathrm{NH}_{3}$, $\mathrm{N}_{2} \mathrm{O}$ and $\mathrm{CH}_{4}$ emissions during passively aerated composting of straw-rich pig manure. Bioresour Technol 98:2659-70. doi:10. 1016/j.biortech.2006.09.021

Turan NG, Ergun ON (2008) Improving the quality of municipal solid waste compost by using expanded perlite and natural zeolite. Clean: Soil, Air, Water 36:330-334. doi:10.1002/clen.200700135

Venglovsky J, Sasakova N, Vargova M et al (2005) Evolution of temperature and chemical parameters during composting of the pig slurry solid fraction amended with natural zeolite. Bioresour Technol 96:181-189. doi:10.1016/j.biortech.2004. 05.006

Villaseñor J, Rodríguez L, Fernández FJ (2011) Composting domestic sewage sludge with natural zeolites in a rotary drum reactor. Bioresour Technol 102:1447-1454. doi:10.1016/j.biortech.2010. 09.085

Wang K, Li X, He C et al (2014) Transformation of dissolved organic matters in swine, cow and chicken manures during composting. Bioresour Technol 168:222-228. doi:10.1016/j.biortech.2014.03. 129

Wei Y-S, Fan Y-B, Wang M-J, Wang J-S (2000) Composting and compost application in China. Resour. Conserv. Recycl 30:277-300. doi: 10.1016/S0921-3449(00)00066-5

Wei Y, Van Houten RT, Borger AR et al (2003) Minimization of excess sludge production for biological wastewater treatment. Water Res 37:4453-4467. doi:10.1016/S0043-1354(03)00441-X

Weiske A, Benckiser G, Herbert T, Ottow JCG (2001) Influence of the nitrification inhibitor 3,4-dimethylpyrazole phosphate (DMPP) in comparison to dicyandiamide (DCD) on nitrous oxide emissions, carbon dioxide fluxes and methane oxidation during 3 years of repeated application in field experiments. Biol Fertil Soils 34:109117. doi: $10.1007 / \mathrm{s} 003740100386$

Yang J, Li X, Xu L et al (2013) Influence of the nitrification inhibitor DMPP on the community composition of ammonia-oxidizing bacteria at microsites with increasing distance from the fertilizer zone. Biol Fertil Soils 49:23-30. doi:10.1007/s00374-012-0692-3

Yang G, Zhang G, Wang H (2015) Current state of sludge production, management, treatment and disposal in China. Water Res 78:60-73. doi:10.1016/j.watres.2015.04.002

Yu QG, Chen YX, Ye XZ et al (2007) Influence of the DMPP (3,4dimethyl pyrazole phosphate) on nitrogen transformation and leaching in multi-layer soil columns. Chemosphere 69:825-831. doi:10.1016/j.chemosphere.2007.05.047

Yu Q, Ma J, Zou P et al (2014) Effects of combined application of organic and inorganic fertilizers plus nitrification inhibitor DMPP on nitrogen runoff loss in vegetable soils. Environ Sci Pollut Res 22:472-481. doi:10.1007/s11356-014-3366-x

Zerulla W, Barth T, Dressel J et al (2001) 3,4-Dimethylpyrazole phosphate (DMPP) - a new nitrification inhibitor for agriculture and horticulture. Biol Fertil Soils 34:79-84. doi:10.1007/s003740100380

Zhang J, Cai X, Qi L et al (2015) Effects of aeration strategy on the evolution of dissolved organic matter (DOM) and microbial community structure during sludge bio-drying. Appl Microbiol Biotechnol 99:7321-7331. doi:10.1007/s00253$015-6640-z$

Zhi W, Ji G (2014) Quantitative response relationships between nitrogen transformation rates and nitrogen functional genes in a tidal flow constructed wetland under $\mathrm{C} / \mathrm{N}$ ratio constraints. Water Res 64:3241

Zhong J, Wei Y, Wan H et al (2013) Greenhouse gas emission from the total process of swine manure composting and land application of compost. Atmos Environ 81:348-355. doi:10. 1016/j.atmosenv.2013.08.048

Zuokaite E, Zigmontiene A (2013) Application of a natural cover during sewage sludge composting to reduce gaseous emissions. Pol J Environ Stud 22:621-626 